\title{
Portrait of Maulana's Life: A Wealthy, Independent, and Outstanding Student
}

\author{
Nafa Izah *, (D) Nanang Martono (i) and Mintarti \\ Department of Sociology, Faculty of Social and Political Sciences, \\ Universitas Jenderal Soedirman, 53122, Purwokerto, Central Java Province, Indonesia \\ * Corresponding Author: nafa.izah@mhs.unsoed.ac.id
}

\section{ARTICLE INFO}

\section{Publication Info:}

Research Article

How to cite:

Izah, N., Martono, N., \& Mintarti, M. (2020). Portrait of Maulana's

Life: A Wealthy, Independent, and Outstanding Student. Society, 8(2), 707-718.

DOI: $10.33019 /$ society.v8i2.240

Copyright (C) 2020. Owned by Author(s), published by Society

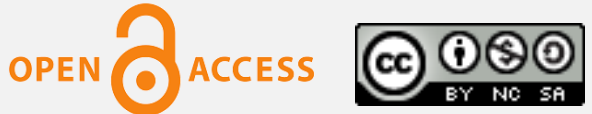

This is an open-access article.

\section{License: Attribution- \\ NonCommercial-ShareAlike (CC BY-NC-SA)}

Received: September 29, 2020; Accepted: November 30, 2020; Published: December 30, 2020;

\begin{abstract}
This study aims to describe a wealthy student's habitus who does not get enough attention from parents but can make school achievements. Parents' role is vital in children's learning development process and becomes an encouragement to increase children's enthusiasm for learning. In this case, wealthy students with achievements are often seen as something normal. However, upper-class students who do not get enough attention from their parents because of being busy at work but can make achievements are exciting things to study, especially to observe the habitus that shapes them. This study uses a qualitative method with a life history approach. This study's single informant is Maulana, a high school student in Cilacap city, Central Java Province, Indonesia. Selection of informant using a purposive sampling technique. The study results indicate that a separate living house forms the habitus of Maulana as an independent student. Independent, in this case, means that he has the initiative to learn without coercion. The achievements he made were a form of strategy to attract the attention of his parents. The achievements that are always compared to his older siblings have boosted Maulana's enthusiasm to improve his achievements. In this case, the study results stated that the habitus is formed from the capital (social, economic, cultural, and symbolic) of the individual. Parents' busyness is not a problem in getting their performance at school.
\end{abstract}

Keywords: Achievement; Habitus; Wealthy Student; Social Inequality

Copyright (C 2020. Owned by Author(s), published by Society. This is an open-access article under the CC-BY-NC-SA license. 


\section{Introduction}

Social inequality is a social issue that still exists today because it has many implications in society's social life. According to Bourdieu, inequality can be found in educational practices and other social institutions (Martono, 2017). Social status differentiation becomes a mechanism that limits some groups from accessing public facilities, including schools. For this reason, the education system is often positioned as a social institution that perpetuates social inequality (Edgerton et al., 2012). Habitus and cultural capital are described in education as an institutional system that perpetuates social reproduction (Weininger \& Lareau, 2018). The education system in schools is one of the institutions that perpetuate the social reproductive system, causing many imbalances in the education system. Expensive schools are very accessible to these upper-class students (Martono, 2019). As a result, the upper-class has easier access to education with the capital they have.

However, inequality in education concerns the differentiation of poor and wealthy students' access to quality education facilities. However, both of them then have different abilities when "faced" with the need to achieve. The economic capacity has differentiated the two groups of students (poor and rich) to achieve an education. Upper-class students have a greater chance of achieving because they have a lot of "capital". This capital is not only economic capital but also includes social, cultural, and symbolic capital.

The family becomes one of the parties that play the role of "fulfilling" these assets through attention, support, and appreciation to increase children's enthusiasm for learning. Environmental factors also contribute to the formation of ways of thinking, such as with whom children hang out, which will significantly affect children's learning achievement. Besides, the facility also determines student-learning success. Wealthy students tend to get facilities quickly to support the learning process, while poor students have limited learning facilities, which then become an obstacle for students to get learning resources (Martono, 2019). The availability of school facilities is also an obstacle for lower-class students to catch up with upper-class students. The limited learning facilities that are owned can make the learning process not run optimally (Prianto \& Putri, 2017). Bourdieu developed the concept of cultural capital in 1970 to explain how a higher class or capable socioeconomic backgrounds get privileges in education (Bourne, 2015).

The role of parents in the development of student achievement is also very much needed. Parents can act as educators; not only teaching but parents can observe the development of their children's interests and talents at the same time (Umar, 2015). Parents have expectations of their children in their performance at school. Many parents prefer to provide many facilities to support the learning process rather than spending time with family. Some parents choose to be busy with their work, so they often ignore the development of their children in the learning process but demand more on children's achievement at school (Umar, 2015).

Habitus was founded primarily in the family, then the community and schools that played their role (Riley, 2017). This explanation shows that family support has a significant contribution to support student achievement. This support is not only material support, but students also need non-material support to achieve school achievements. Some students can excel even though they can be "lacking" support or attention from their parents. This phenomenon experienced by some students is interesting to study, especially for students from the upper-classes.

For this reason, this study describes the social life of a "rich student" who achieves even though they "get less" attention from their parents because they are busy working. Parents" important factor as a control system for a child is not sufficient for the figure of Maulana.

Copyright (C 2020. Owned by Author(s), published by Society. This is an open-access article under the CC-BY-NC-SA license. https://doi.org/10.33019/society.v8i2.240

708 
However, according to Bourdieu's theory of cultural capital, upper-class parents transmit cultural capital to preserve their social status (Tan, 2017).

Maulana (not his real name) is one of the students from an upper-class family who does well in school. He is a high school student in the city of Cilacap. Maulana's life is unique. Physically he rarely meets his parents because they are busy working. In other words, the figure of Maulana is "a child who rarely gets direct parental attention". Umar (2015) stated that parents' role in the development of student achievement is needed. In supporting the achievement of children's learning achievement, parents play a role in educating, motivating, and facilitating children's learning even though they have taken education and learned at school. However, parents' concern for children's education significantly affects the success of children's achievement.

Research conducted by Sinaga (2018) stated that parental support for children's learning is needed. Parents' involvement plays a significant role in children's development. One of the effects of parental involvement is that children can succeed in school because parents support and are involved in children's education. The role of parents in the development of children's education is needed. This support also encourages children's achievement in school, with attention, love, and care in children's learning process at home.

This study's novelty provides new evidence that students who excel do not always get parental support, mainly psychological or moral support. Maulana's figure is a picture of students from affluent families who can excel even though both parents do not pay enough psychological attention. The aspect that distinguishes this research from other studies is that wealthy students who do not get their parents' attention can do well. The control system in Maulana's learning pattern can be said to be minimal. However, the expectations and demands of parents for their children to excel in school are very high.

\section{Literature Review}

\subsection{Understanding the Role of Class Habitus in Educational Success}

Bourdieu's study of the concept of habitus has been published in many scientific books and journals, consisting of: "Distinction: A Social Critique of The Judgment of Taste", "Arena Produksi Kultural: Sekolah Kajian Sosiologi Budaya”, "Bourdieu's Class Theory: The Academic as Revolutionary", "Pierre Bourdieu's Sociology of Education: Institutional Form and Social Inequality ", and others. Habitus is a part studied in the first socialization, namely the family, which forms an individual's view of the world, including the perception of what is possible and like in a social position. Habitus is a structure that is formed and forms (Adib, 2012). In other words, habitus is the structure and social agent as individuals who help shape and understand social life. According to Bourdieu (2012), considers that social reality as a typology of space in which there are various fields, such as politics, art, culture, education, economy, religion, and others.

Habitus is formed because of the existence of capital. Bourdieu defines capital not only in material form but also as the result of work accumulated in a distorted form or grows in the individual (Umanailo, 2018). Bourdieu mentions four capital types: economic capital, symbolic capital, cultural capital, and social capital. Bourdieu developed the concept of cultural capital in 1970 to explain how a higher class or well-off socioeconomic backgrounds get privileges in education (Bourne, 2015). Bourdieu's most well-known concepts are habitus and cultural capital as the main mechanisms of class domination. Habitus and cultural capital are described in education as an institutional system that perpetuates social reproduction (Weininger \& Lareau, 2018). 
Habitus is associated with class domination, which shapes one's behavior. In education, wealthy students tend to bring out their characteristics to reflect their class identity. However, habitus has a strong effect on student achievement. Wealthy students have enough capital to carry out their habits so that it is easier to achieve success in education (Martono, 2019).

According to Bourdieu, understanding class differences in educational success requires understanding habitus' effect on class differences and cultural capital on student academic practice (Edgerton et al., 2012). Habitus is partly developed through experience or social interaction. Bourdieu sees education as an institution to develop its habitus as an aim to perpetuate the social system.

One of Bourdieu's claims to habitus theory is that it is a practical system of dispositions, rewards, and mastery, which are products and consequences of one's class position. His claims indicate a close relationship between deep and strong class position schemas (Riley, 2017). In simple terms, the conceptual scheme of Bourdieu's theory, namely one's schema of resources (capital), can produce a character structure (habitus) resulting from certain behaviors in a particular social context. In the end, habitus is a manifestation of one's social class (Riley, 2017).

Research conducted by Edgerton et al. (2012) shows that habitus has a powerful effect on academic practice. Mainly the home environment rather than the school environment influences students' dispositions and practices. Academic achievement is influenced by habitus and gender between men and women. Male students excel in mathematics, while female students excel in reading. In this case, the habitus has a positive effect on academic achievement. Another study was conducted by Saehu et al. (2018), which discussed the formation of accelerated class students' habitus at Jakarta 65 Public Senior High School. Accelerated classes encourage students to achieve good academic performance. Habitus formed in accelerated classes is discipline, perseverance, and competition, which requires students to follow fast learning patterns.

Habitus, in this case, is used as a means of realizing class domination supported by capital. Habitus is manifesting structural changes in the social environment. In this case, Bourdieu views habitus as a form of manifestation of a particular class based on resources (capital) that shape behavior patterns. In previous studies, schools as social institutions were targeted in the formation of habitus. Resources (capital) have a strong influence in shaping habitus. The upperclass who has sufficient capital can quickly achieve academic achievement with the help of sufficient resources.

\subsection{Habitus as Capital in Achievement}

Habitus is a social value that humans live. It is created through the socialization process, forming a way of thinking and behavior patterns that remain in the individual (Umanailo, 2018). Habitus is formed in families, communities, and schools (Riley, 2017). The family is the first socialization agent for children, through interactions between family members causing the exchange of information and lifestyles, shaping various behaviors based on social capital. Social capital refers to a set of resources associated with the ownership of a network of relationships that know or recognize each other that provides capital support (Umanailo, 2018). Bourdieu argues that individuals from different social classes have an intricate understanding of specific social field conditions (Edgerton et al., 2012). In other words, there are differences in behavior when acting in response to certain conditions. For example, parents in socioeconomic conditions who can provide learning facilities for their children, but with their busy activities tend to interact less closely with children. In terms of financial ability, upper-class parents facilitate learning support for children's school success.

Copyright (C 2020. Owned by Author(s), published by Society. This is an open-access article under the CC-BY-NC-SA license. 
Cultural capital is a way of operating in a social environment. According to Bourdieu's theory of cultural capital, upper-class parents transmit cultural capital to preserve their social status. There are three mechanisms for preserving cultural capital: being objectified, realized, and institutionalized (Tan, 2017). In Bourdieu's view, objectivism is objective knowledge conveyed through a domination mechanism so that individuals cannot resist. This domination occurs due to encouragement from outside the individual (Umanailo, 2018). In this case, institutionalized meaning, for example, schools, social institutions that use the reproductive function to preserve social status. In this case, the habitus is embodied and institutionalized in educational institutions, namely schools.

The results of the interaction between children and parents also shape changes in behavior patterns. Not a few parents provide facilities that reflect upper-class identity as a form of perpetuating their social status. For example, parents give four-wheeled vehicles to children to go to school. This action is done to show the identity of the class (upper-class). Cultural capital developed at school helps a person gain academic success at school, forming student habitus. Habitus, in this case, has a strong influence in the presence of capital as a resource. Students from the upper-class have substantial capital to have higher grades in school. Academic achievement is influenced by the socioeconomic conditions of parents who can help support student learning facilities. Upper-class habits developed in schools are then formed and followed by lower-class students as a habit carried out unconsciously.

Research conducted by LH \& Syukur (2016) showed that there are several learning habits of outstanding students in schools, including learning concentration as the center of attention on learning situations, which are the students' focal point. Other habits include listening to the teacher, actively asking questions during class, reading frequently, and taking notes. Habitus of high-achieving students at home can include scheduling and implementation. Students are more organized and focused, setting the study's duration, which is mostly done at night, repeating lesson material as a reminder of the material taught at school, doing assignments, then memorizing or understanding material reviewed.

Caprara (2016) researched the impact of cultural capital on students in Brazil shows that student cultural capital substantially impacts students' appearance. The cultural capital that is easy to have is the level of parental education. In this case, mothers who have taken tertiary education tend to get higher points and education levels. This shows that parental higher education has an impact on student academic achievement. Students who have many books at home also tend to have high academic achievement. Thus, socioeconomic conditions show an essential relationship in student achievement.

Another research conducted by Sinaga (2018) on the level of parental support for student learning shows that most parents have a very high carrying capacity for children's learning, as evidenced by the majority of students' parents pay attention to their children's education. Meanwhile, four parents who have a low carrying capacity for children's learning indicate that school support is needed to help parents build a support system for student learning. The low carrying capacity of parents towards children's learning is due to the absence of concrete parents.

The three studies indicate that each student has specific social capital. High achieving students are supported by students' encouragement to be independent, forming their habit in learning patterns. This is supported by socioeconomic conditions that affect the level of capital held. High resources (capital), in this case, can support high achieving students. Parents with sufficient socioeconomic conditions can become capital in supporting learning facilities. Social capital with parents who support student learning can provide learning encouragement to

Copyright (C 2020. Owned by Author(s), published by Society. This is an open-access article under the CC-BY-NC-SA license. 
support their school achievement level. The social capital in the family then forms the pattern of student behavior (habitus).

\section{Research Methodology}

This study is a qualitative study using the life history approach. Life history is one of the many forms of narrative that can effectively describe a person's life story (Tierney \& Lanford, 2019). This study's life history approach was to determine the habitus of wealthy students who were able to excel even though they did not get enough attention from their parents. Selection of informant using a purposive sampling technique with specific considerations or unique selection (Siyoto \& Sodik, 2015). This consideration is made of informants who match the target criteria, namely students who are wealthy, independent, and outstanding. This study's single informant is Maulana, a high school student in Cilacap city, Central Java Province, Indonesia. The study location was carried out at the school where Maulana was studying.

Data collection is carried out in the following stages:

a) In-depth interview, the interview process is carried out to obtain data and information by asking the questions. The questions asked used interview guidelines to be more focused.

b) Observation, the observation process is carried out by observing school facilities and learning facilities' condition.

c) Documentation, the documentation process is carried out to trace historical data. Documentation, in this case, is done by recording interviews.

After data has been collected, the next step is the data analysis stage, which is carried out by reducing the data, presenting the data, and drawing conclusions. Meanwhile, the data validity test used the source triangulation technique. Data and information to test the data's validity were carried out by interviewing the counseling guidance teacher.

\section{Results and Discussion}

\subsection{Results}

Maulana is a Science grade 12 student at a Public High School in Cilacap city. He is the third of three children. His first brother is currently pursuing a master's degree, while his second brother works at Petrogas. His father works in a state-owned company, and his mother is a notary. Maulana is a son of a very well-off family, socially and economically, so that his parents can provide learning facilities. These facilities are used as learning support tools, such as laptops, cell phones, and the money to buy books every month. Maulana is a figure who likes to read books, especially comics and novels in English. Besides, from Elementary School to Senior High School, Maulana attended tutoring in private. Maulana also gets money every month for his needs, Rp300,000 from his mother and Rp750,000 from his father. Maulana manages the monthly money for transportation, buying books, and saving.

At school, Maulana was known as a smart, intelligent, and outstanding student. From grade 1 elementary school to grade 6 elementary school, he is always in the top five and the top three. However, when he entered junior high school, his achievement decreased due to the curriculum change to the 2013 curriculum. When the 2013 curriculum was implemented, Maulana was less able to adjust, so that his grades in grade 7 decreased. However, when the 8th-grade curriculum at school returned to using the KTSP curriculum (Education Unit Level Curriculum), he managed to get first place in semester one and second place in semester 2. Then in grade 9, Maulana was ranked 5 in semester one and rank 9 in semester 2 . The decline in achievement was due to competition between students, which was considered quite heavy. However, at 
Junior High School National Examination, Maulana again achieved his achievement by being ranked fifth in the school. The development of his achievement always increases his inner drive to more increase his performance in school.

After junior high school, Maulana immediately enrolled in a public high school in Cilacap city with very satisfying junior high school grades. Maulana is a figure with considerable ambition, with role models that he follows: his brother and father. Maulana did not want to be outdone by his brother's achievements or successes, which succeeded in continuing his studies at a university in Yogyakarta. The success of his brother became a source of motivation for Maulana to study. According to him, parents often compare his achievements with those of their siblings. This became one of the motivations for Maulana to be better than his brothers did.

Maulana used to spend time at home with his parents on weekends. Communication with his family is only done through social media. The condition of Maulana's home, which was separated from his father, who works in Jakarta and only lives with his mother, who also busy at work, made Maulana often feel neglected by his parents.

At home, Maulana has a household assistant. This does not necessarily make Maulana a person who always relies on household assistants. He often helps his father wash the car or help his mother every weekend. Spending time with his parents on weekends is a rare moment, as Maulana said:

"For the weekend, my father came home Friday night. Most of the weekends I spend with my father and mother, sometimes accompanying my father to wash the car".

At other times, Maulana often gathered with his friends. It is not uncommon for his friends to invite Maulana to study, discuss school materials, and work on joint problems.

Maulana is an active student in the organization in his school. During high school, Maulana attended the student council for one period. However, seeing his grades drop in 10th grade caused Maulana to decide to leave the student council in grade 11 and focus on increasing grades. Maulana could not divide his time well between the academic and non-academic fields, which caused his grades to decline. In junior high school, Maulana attended extracurricular activities in Computer Network Engineering, graphic design, Photoshop, CorelDraw, and others.

Maulana likes biology, math, and English. He is a student who is quite active in his class. Often Maulana asks or answers questions from the teacher during the learning process, as Maulana said:

"If I am confused about the material, I will ask. If not, I will save the question for my self-study. If not, I will ask during lessons".

Maulana also often visits the library to read books or do assignments with friends. Often Maulana spent time in the library just reading books. Maulana's condition, who only lives with his mother, who is busy with her work, is not a problem for Maulana. Since he was a child, he followed tutoring to fill his busy life while waiting for his family at home. Maulana said that he had been waiting for his father to retire for almost eight years. However, when his father retired, his father again received a contract to continue working in State-owned enterprises, so that Maulana could not get together with his parents, as Maulana said: 
"No, I am more depressed because my parents are far away. My father is a retiree but has been contracted again at the company, so I still go home once a week and I waited for his retirement for eight years, so I was from the age of nine until now my father is far away".

His success in achieving school achievements became a strategy to attract his parents' attention. Whenever Maulana got excited about his achievements at school, he did not expect gifts from his parents. Maulana stated:

"Yes, I do not expect them to give my funds. It is okay because if I ask for a gift like, I am shameless".

He also stated:

"I am not satisfied, but when I look at the achievement in semester five compared to semester four, I am satisfied, delighted. However, I do not feel personally satisfied if I have not heard my parents say, "good job, your grades are excellent".

According to him, a gift is not something to look forward to or expect when he achieves his school achievements. Attention from parents is something that Maulana expects in the process of his learning development. Just congratulating him for his achievements is something that Maulana wants. His school progress is proof of his ambition to pursue his dreams, and he does not want to be outdone by his siblings' achievements. His desire for achievement shows a habitus based on strong desire and enthusiasm.

\subsection{Discussion}

The portrait of Maulana's life is due to the habitus that is formed from a capital that is owned, both social capital and economic capital. The description of Maulana's family shows that he lives in a very well-off family environment, so it can be said that Maulana's economic capital is relatively high. Habitusnya formed through social experiences shared with family, friends, school, and the environment in which he lives. Habitus produces behavior that is spontaneous or carried out unconsciously and on purpose (Adib, 2012). In other words, habitus is the structure and social agent as individuals who help shape and understand social life. Besides, habitus is also formed through interaction with the environment (Saehu et al., 2018). The formation of the habitus is none other than due to a person's daily activities. The habitus, in this case, is institutionalized through his daily life as independent and accomplished students.

Parents have an essential role in shaping the habitus of children in school. Parenting patterns can shape the development of children's achievements. Academic achievement can be improved through encouragement and attention from parents in the learning process at school. Turner et al. (2009), as cited in Hedyanti et al. (2016), stated that parents' role in educating children would increase children's learning motivation so that children can achieve. This parenting style can shape a child's personality towards their social world. Growth and development will be determined by providing parenting patterns and parents' role towards children.

Without parental attention or support, wealthy students are prone to deviance because their "capital" is misused to commit deviant behavior. Not a few wealthy students do a spree or hedonistic lifestyle, leading to negative things (Dahayu, 2015). Wealthy students tend to use the 
facilities they have as a form of identity with upper-class habitus as capital. Parents from the upper-class tend to be busy with their work, so they often ignore their role as parents who care for and educate and see the development of their children's lives (Umar, 2015).

Appreciation from parents helps to motivate children. Children tend to feel satisfied when they get appreciation from their parents for their achievements. However, according to Maulana, his parents never gave him appreciation because his brother's performance was better than his. In this case, Bourdieu argues that individuals from different social classes have different behaviors and understandings in certain social field conditions (Edgerton et al., 2012). Upper-class parents who are busy with their activities will choose to give material attention. They tend to be less intimate with their children.

The strategy to attract parental attention is demonstrated through its achievements. This triggered Maulana to have high enthusiasm to excel in school. This is because he expects appreciation from his parents for his achievements. The level of parental support for student learning shows that most parents have a very high carrying capacity for children's learning (Sinaga, 2018).

A separate living house or only living together with his mother makes Maulana an independent person. Maulana, who lives in a separate living house from his father, and his mother, who are busy at work, does not necessarily make him a person who uses his economic capital for personal enjoyment or something that is not useful for his life. He lived his life with his own choice in order to achieve his school achievements. In this case, the concept of forming an independent habitus and achievement has an interrelated relationship. The two concepts indicate a habitus formation, which goes hand in hand.

The social status of Maulana, who came from a well-off family, made it easier for him to reach his habitus. Maulana's socioeconomic status is included in the upper-class category as an economic capital that also forms his habitus. This is the formation of a habitus that supports increased learning achievement. In this case, according to Bourdieu, understanding class differences in educational success requires an understanding of the contribution of habitus ownership to class differences and cultural capital to students' academic practice (Edgerton et al., 2012). Habitus is partly developed through experience or social interaction. In this case, the cultural capital is the school as an institution that is strong enough to encourage student habitus formation. Bourdieu defines education as a reproduction of social class by spreading the dominant social class habitus (Fatmawati, 2020). Bourdieu sees education as an institution to develop the habitus as the goal of perpetuating the social system. The facilities provided in schools represent the cultural symbols of the upper-class, so that in this case, the school is an institution that performs social reproduction. The school encourages the preservation of upperclass habitus (Putri, 2018). In this case, the facility is a support that can encourage the formation of Maulana's figure's habitus. Completeness of facilities that support the learning process that helps shape the habitus in improving achievement in schools.

Another habit that shapes his life is the circle of friends. Maulana's friends often invited him to study together to discuss school material or discuss practice questions. The support and encouragement of a friendly environment has a good impact on his daily life and supports habitus formation. The economic capital he owned did not necessarily make Maulana live casually with his friends. The condition that separated his parents from him made Maulana spends much time playing with his friends or busy following tutoring. Social capital refers to a set of resources with a knowing or acknowledging relationship that can provide support (Umanailo, 2018). In this case, the friendly environment and condition of Maulana, who was separated from his parents, formed an independent and accomplished habitus.

Copyright (C 2020. Owned by Author(s), published by Society. This is an open-access article under the CC-BY-NC-SA license. 
The environment or something outside the individual does not only form the habitus formation. However, something contributes to the habitus of independent and achieving students, namely the encouragement that arises from the individual, such as motivation. Motivation is something that arises from an individual that encourages him to strive to become a better individual. Maulana's motivators who encourage enthusiasm in his life are his brothers and father. This motivator encourages him to have a big enough ambition to become better at achieving and pursuing his dreams. Student achievement can be driven by motivation from within students who can achieve their school achievements (Rahmawati et al., 2017). Even though his parents often compared Maulana's achievements with his brother's, this did not necessarily make him fall. This makes him have a high enough enthusiasm to improve his performance in school. The comparisons made by his parents became a trigger that pushed him to become an outstanding student.

Maulana has a high interest in learning. He followed tutoring based on his wishes. Following study guidance is a need for him that helps improve his performance. He attended tutoring at an institution and attended private tutoring at his teacher's house. His interest in the following tutoring shows that he is an independent student and helps him understand school material.

Habitus can then be formed through ideals. Ideals are different from motivation, but both are related to each other, namely as an incentive to have high enthusiasm in realizing dreams. Ideals are dreamed of, while motivation can be used as a trigger in pursuing dreams or ideals. Maulana aspires to be able to continue his education to a higher level. These ideals are stimulated by role models' existence, namely his brother and father, who can encourage Maulana's enthusiasm to realize his goals. The role model is a trigger that can inspire him to achieve his achievements.

Although in the material needs of Maulana, it can be said that all his needs are fulfilled. Then the materials and facilities have a substantial impact on the formation of the habitus. These conditions helped shape the habitus and life of Maulana by carrying out all the activities supported by the formation of his habitus as a rich, independent student and successfully carve his achievements in school.

\section{Conclusion}

Habitus is formed on respective capital, either social, economic, cultural, and symbolic. The portrait of Maulana's life as a wealthy student who does not get enough attention from parents can make achievements due to his capital. Maulana's desire for achievement is relatively strong. His achievement capital is formed by a role model existence, namely his brother, who encourages his enthusiasm for learning. Although Maulana's achievements are often compared to his older siblings, this does not necessarily diminish his learning enthusiasm. This can motivate Maulana to continue to improve his achievements. Besides, achievement capital can be a strategy to get the attention of parents. Lack of attention from parents psychologically is not an obstacle to Maulana's achievement. However, this can trigger high enthusiasm to increase his performance.

\section{Acknowledgment}

The authors are grateful to express gratitude to those who have had the pleasure to cooperate during this study. 


\section{Declaration of Conflicting Interests}

The authors have declared no potential conflicts of interest concerning the study, authorship, and/or publication of this article.

\section{References}

Adib, M. (2012). Agen dan Struktur dalam Pandangan Piere Bourdieu. BioKultur, I(2), 91-110. Retrieved from http://journal.unair.ac.id/download-fullpapers-01 Artikel AGEN DAN STRUKTUR DALAM PANDANGAN PIERE BOURDIEU Revisi 20 Okt 2012.pdf

Bourdieu, P. (2012). Arena Produksi Kultural : Sebuah kajian sosiologi budaya. (I. R. Muzir, Ed.). Bantul, Indonesia: Kreasi Wacana.

Bourne, M. (2015). Social-Class Inequality in Educational Attainment and Participation in England (Doctoral's dissertation). The University of Manchester. Retrieved from https:/ / www.research.manchester.ac.uk/portal/en/theses/socialclass-inequality-ineducational-attainment-and-participation-in-england(089d81d7-88c3-474a-b73f1d00432fbd6e).html

Caprara, B. (2016). The Impact of Cultural Capital on Secondary Student's Performance in Brazil. Universal Journal of Educational Research, 4(11), 2627-2635. https://doi.org/10.13189/ujer.2016.041116

Dahayu, R. (2015). Pembentukan Kelompok dan Gaya Hidup Hedonis: Studi Kasus Pada Siswa SMAN 9 Pekanbaru. Jom FISIP, 2(1), 1-10.

Edgerton, J. D., Roberts, L. W., \& Peter, T. (2012). Disparities in Academic Achievement: Assessing the Role of Habitus and Practice. Social Indicators Research, 114(2), 303-322. https:/ / doi.org/10.1007/s11205-012-0147-0

Fatmawati, N. I. (2020). Pierre Bourdieu Dan Konsep Dasar Kekerasan Simbolik. Madani Jurnal Politik Dan Sosial Kemasyarakatan, 12(1), 41-60. Retrieved from http://www.ejurnal.unisda.ac.id/index.php/MADANI/article/view/1899

Hedyanti, W. N., Sudarmiatin, S., \& Utaya, S. (2016). Pengaruh Pola Asuh Orangtu A terhadap Prestasi Belajar IPS melalui Motivasi Belajar (Studi pada Siswa Kelas IV, V, VI Gugus 2 Kecamatan Ngantang Kabupaten Malang). Jurnal Pendidikan: Teori, Penelitian, dan Pengembangan, 1(5), 865-873. Retrieved from http://journal.um.ac.id/index.php/jptpp/article/view/6289

LH, N., \& Syukur, M. (2016). Habitus Belajar Siswa Berrestasi di SMA Negeri 12 Makassar. Jurnal Sosialisasi Pendidikan Sosiologi-FIS UNM, 3(2), 136-142. Retrieved from http:/ / ojs.unm.ac.id/sosialisasi/article/view/2376

Martono, N. (2017). Kekerasan Simbolik di Sekolah Sebuah Ide Sosiologi Pendidikan Pierre Bourdieu. Depok, Indonesia: PT Rajagrafindo Persada.

Martono, N. (2019). Sekolah Inklusi Sebagai Arena Kekerasan Simbolik. Sosiohumaniora : Jurnal Ilmu-Ilmu Sosial Dan Humaniora, 21(2), 150-158. https:/ / doi.org/10.24198/sosiohumaniora.v21i2.18557

Prianto, A., \& Putri, T. H. (2017). Pengaruh Ketersediaan Fasilitas Belajar, Dukungan Orang Tua Yang Dirasakan Terhadap motivasi Dan Prestasi Belajar Siswa SMA PGRI Ngimbang Lamongan. Jurnal Pendidikan Ekonomi, Kewirausahaan, Bisnis, Dan Manajemen (JPEKBM), 1(2), 13-38. Retrieved from https:/ / ejournal.stkipjb.ac.id/index.php/ekonomi/article/view/475

Putri, S. Z. (2018). Sekolah Formal Sebagai Arena Reproduksi Kelas Sosial (Studi terhadap Reproduksi Kelas Sosial di SMA Negeri 1 Depok) (Thesis). Universitas Islam Negeri Syarif 
Hidayatullah.

Retrieved

from

http:/ / repository.uinjkt.ac.id/dspace/handle/123456789/43596

Rahmawati, N., Mudjiran, M., \& Yusri, Y. (2017). Hubungan Pengasuhan Orangtua dengan

Motivasi Berprestasi Siswa yang Berasal dari Keluarga Miskin di Kota Padang. Jurnal

EDUCATIO: Jurnal Pendidikan Indonesia, 3(2), 1. https:/ / doi.org/10.29210/120172100

Riley, D. (2017). Bourdieu's class theory: The academic as revolutionary. Catalyst: A Journal of

Theory and Strategy, 1(2), 107-136. Retrieved from https://catalystjournal.com/vol1/no2/bourdieu-class-theory-riley

Saehu, R., Suriani., \& Clara, E. (2018). Pembentukan Habitus Siswa CI/BI dalam Kelas

Akselerasi di SMA Negeri 65 Jakarta. Jurnal Analisa Sosiologi, 7(1), 85-93. Retrieved from https://jurnal.uns.ac.id/jas/article/view/18734/16566

Sinaga, J. D. (2018). Tingkat Dukungan Orang Tua Terhadap Belajar Siswa. Indonesian Journal of Educational Counseling, 2(1), 43-54. https:/ / doi.org/10.30653/001.201821.19

Siyoto, S., \& Sodik, A. (2015). Dasar Metodologi Penelitian. Yogyakarta, Indonesia: Literasi Media

Publishing.

Tan, C. Y. (2017). Examining Cultural Capital and Student Achievement: Results of a MetaAnalytic Review. Alberta Journal of Educational Research, 63(2), 139-159. Retrieved from https://cdm.ucalgary.ca/index.php/ajer/article/view/56285

Tierney, W. G., \& Lanford, M. (2019). Life History Methods. In P. Atkinson, S. Delamont, A.

Cernat, J.W. Sakshaug, \& R.A. Williams (Eds.), SAGE Research Methods Foundations. https:// doi.org/10.4135/9781526421036750846

Umar, M. (2015). Peranan Orang Tua Dalam Peningkatan Prestasi Belajar Anak. JURNAL

EDUKASI: Jurnal Bimbingan Konseling, 1(1), 20. https:/ / doi.org/10.22373/je.v1i1.315

Umanailo, M. C. B. (2018). Mengurai Kekerasan Simbolik di Sekolah: Sebuah Pemikiran Pierre Bourdiue Tentang Habitus dalam Pendidikan. https:/ / doi.org/10.13140/RG.2.2.24809.80483

Weininger, E. B., \& Lareau, A. (2018). Pierre Bourdieu's Sociology of Education: Institutional Form and Social Inequality. In T. Medvetz \& J. J. Sallaz (Eds.), The Oxford Handbook of Pierre Bourdieu (pp. 253-272). Oxford, United Kingdom: Oxford University Press. https:/ / doi.org/10.1093/oxfordhb/9780199357192.013.11

\section{About the Authors}

1. Nafa Izah, an undergraduate student at Department of Sociology, Faculty of Social and Political Sciences, Universitas Jenderal Soedirman, Indonesia.

E-Mail: nafa.izah@mhs.unsoed.ac.id

2. Nanang Martono, obtained his Doctoral degree from Université Lumière Lyon 2, France, in 2017. The author is an Assistant Professor at the Department of Sociology, Faculty of Social and Political Sciences, Universitas Jenderal Soedirman, Indonesia.

E-Mail: nanang.martono@unsoed.ac.id

3. Mintarti, obtained her Doctoral degree in Sociology from Universitas Padjadjaran, Indonesia, in 2019. The author is an Associate Professor at the Department of Sociology, Faculty of Social and Political Sciences, Universitas Jenderal Soedirman, Indonesia.

E-Mail: mintarti@unsoed.ac.id

Copyright (C 2020. Owned by Author(s), published by Society. This is an open-access article under the CC-BY-NC-SA license. 